\title{
ELIMINATION OF NEGATIVE CHARACTER FEATURES AS AN ELEMENT OF BUILDING A POSITIVE IMAGE OF PHYSICAL EDUCATION TEACHER
}

\author{
The image of the teacher in the eyes of a student
}

\author{
MIROSŁAW ZALECH
}

\author{
The Josef Pilsudski University of Physical Education in Warsaw, Faculty of Physical Education \\ and Sport in Biata Podlaska, Department of Management
}

\author{
Mailing address: Mirosław Zalech, Faculty of Physical Education and Sport, 2 Akademicka Street, \\ 21-500 Biała Podlaska, tel.: +48 83 3428784, fax: +48 83 3428800, e-mail: miroslaw.zalech@awf-bp.edu.pl
}

\begin{abstract}
Introduction. In the era of the development of a number of ways and forms of communication, positive image has become an important medium of information, including teacher-student relationships. One can now recognize it as one of the elements of effective implementation of the mandates of teaching and upbringing. The aim of this study was to determine what physical education teacher's features are most undesirable for senior high school students, and thus negatively affect his image. Material and methods. The study used the method of diagnostic survey, in which the questionnaire technique was used. The data obtained from 763 students of two senior high schools (484 females and 279 males) was analyzed. For statistical evaluation of the data the log-linear analysis method was used. Results. Quick temper and severity were found to be the features that the students found to be most undesirable in the physical education teacher. The choice of such features as: compliant, indulgent, moody and quick tempered was significantly dependent on gender ( $\mathrm{p}<0.05)$, and such as strict, hesitant and distracted, significantly depended on both gender and grade $(\mathrm{p}<0.05)$. The school turned out to be a variable that did not differentiate significantly choices made by students. None of the independent variables conditioned the selection of such features as passive and unreliable. Conclusions. Knowing what features should not characterize a physical education teacher is one of the important elements that should be taken into account in the process of building a positive image of teachers. It can be assumed that the elimination or restriction of the expression of these features contributes significantly to the positive perception of teachers, and it is followed by improved relations with students and increased effectiveness of teaching and educational interactions.
\end{abstract}

Key words: image, features, public relations

\section{Introduction}

The image is the idea of space [1], persons [2], organizations [3]. This idea arises in the mind of a person through direct contact with the entity, whose image is created, as well as through information received from the media or other sources [4]. This image consists of several elements, among others, such as appearance, manner of verbal and nonverbal communication, behaviour, and all activities and information that arrive and are evaluated by persons forming the image [5]. The image has to inform others about who you are, what values you represent, what purposes you pursue [6]. These not necessarily have to be the actual values, but such that the person wants to convey to others. The image can be viewed in two grasps. Narrower, as a subjective feeling of the person, and the wider, objective, as the group perception. In the era of the development of a number of ways and forms of communication, the need to be properly perceived is one of the methods of effective implementation of tasks and meeting the expectations posed [7]. Achieving this requires the identification of the elements forming the image. Understanding of both desirable and undesirable components creates the possibility of using this knowledge to build positive image of one in the minds of others.
The aim of this study was to determine what features of physical education teachers are most undesirable for high school students. The problem also refers to indicating whether gender, grade, school, significantly affect the selection of individual features.

\section{Material and methods}

The study was conducted among 813 students of two senior high schools (1SHS, 2SHS) randomly selected from one of the cities of Lubelskie Voivodeship. The method that was used in the study was a diagnostic survey. Respondents were asked the questions (semi-open), in which they were asked to identify three characteristics which a physical education teacher should not have. This task was correctly implemented by the 763 individuals, 405 of the 1 SHS and 358 of 2SHS (Tab. 1). The largest group consisted of students of grade II, and least numerous of grade I (Tab. 1). For simultaneous analysis of four variables the log-linear analysis was used. Calculations were performed using Statistica 8 application. The reliability of the assessment tool was made after the pilot studies $(n=63)$ using the kappa coefficient of compliance. The results obtained in the first survey (test) were 
then compared with the results of re-examination, which took place a week later (retest). Kappa coefficient was 0.91 .

Table 1. Respondents by school, gender and year of teaching

\begin{tabular}{|c|c|c|c|c|c|c|c|c|}
\hline \multirow{3}{*}{ Grade } & \multicolumn{3}{|c|}{ Senior high school (1) } & \multicolumn{3}{c|}{ Senior high school (2) } \\
\cline { 2 - 9 } & Females & \multicolumn{2}{|c|}{ Males } & \multicolumn{2}{c|}{ Females } & \multicolumn{2}{c|}{ Males } \\
\cline { 2 - 9 } & $\mathrm{n}$ & $\%$ & $\mathrm{n}$ & $\%$ & $\mathrm{n}$ & $\%$ & $\mathrm{n}$ & $\%$ \\
\hline I & 83 & 10.88 & 50 & 6.55 & 60 & 7.86 & 25 & 3.28 \\
\hline II & 88 & 11.53 & 37 & 4.85 & 95 & 12.45 & 75 & 9.83 \\
\hline III & 80 & 10.48 & 67 & 8.78 & 78 & 10.22 & 25 & 3.28 \\
\hline Total & 251 & 32.90 & 154 & 20.18 & 233 & 30.54 & 125 & 16.38 \\
\hline
\end{tabular}

\section{Results}

The obtained data (Fig. 1) show that the most undesirable features of physical education teacher include: quick temper, a feature that was indicated by more than $65 \%$ of the respondents, almost $15 \%$ less - severity. On the third and fourth place there were such features as unreliability and moodiness. Least of respondents $(n=19)$ listed features that were not included in the response options. According to these respondents, physical education teacher should not be characterized by such features as: lazy, rude, biased, careless, intolerant.

Table 2 shows that the calculated statistics for models of all the secondary and tertiary features were significant $(p<0.01)$, therefore the hypothesis of independence of the choices made by respondents in relation to gender, school they attend and grade they learn were rejected. It means that the inclusion of a thirdgrade interaction for these models will improve their adjustment, while broadening the fourth-grade interactions will not contribute to their significant improvement.

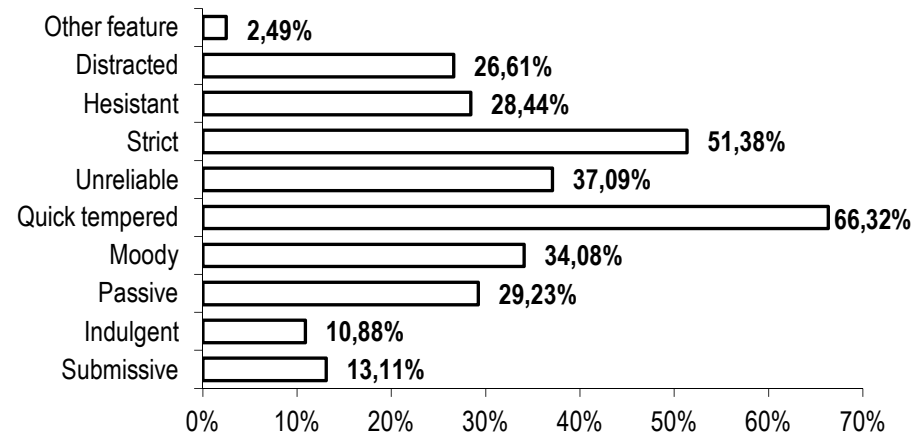

Key: respondents chose three features, thus interes did not summed to $100 \%$.

Figure 1. Interes of indications of particular features made by respondents $(n=763)$

Tests of partial and marginal association for passive and unreliable features, revealed no correlation between independent variables and the dependent variable. Discovered links between the independent variables did not show their impact on the choice of a particular feature (dependent variable) and therefore were excluded from further analysis.

Log-linear analysis of the observed number of selected properties such as: strict, hesitant and distracted, showed that they depended significantly on gender and grade $(\mathrm{p}<0.05)$. Significant second-grade interactions $(\mathrm{p}<0.01)$ were revealed between gender of respondents, and features selected: compliant, indulgent, moody and quick tempered (Tab. 3).

Male respondents more often pointed to submissive and indulgence than girls, as those features which are most undesirable in the physical education teacher (respectively 1.85 and 1.76 times more often). The girls more often than boys consid- ered being moody as undesirable (1.84 times) as well as quick tempered (1.19 times).

Table 2. Results matching all the k-factor interactions of the model analyzed

\begin{tabular}{|c|c|c|c|c|c|}
\hline \multirow{2}{*}{ Feature } & $\mathrm{K}^{\star \star \star \star}$ & 1 & 2 & 3 & 4 \\
\hline & $\mathrm{df}^{* \star}$ & 5 & 9 & 7 & 2 \\
\hline \multirow{2}{*}{ Submissive } & $\chi^{2 *}$ & 526.130 & 41.252 & 23.885 & 2.941 \\
\hline & p-level & .000 & .000 & .001 & .230 \\
\hline \multirow{2}{*}{ Indulgent } & $\chi^{2 *}$ & 584.230 & 36.987 & 21.574 & 1.523 \\
\hline & p-level & .000 & .000 & .003 & .467 \\
\hline \multirow{2}{*}{ Passive } & $\chi^{2} *$ & 200.402 & 27.182 & 23.131 & 1.176 \\
\hline & p-level & .000 & .001 & .002 & .555 \\
\hline \multirow{2}{*}{ Moody } & $\chi^{2 *}$ & 119.320 & 56.937 & 26.221 & 1.350 \\
\hline & p-level & .000 & .000 & .000 & .509 \\
\hline \multirow{2}{*}{ Quick tempered } & $\chi^{2 *}$ & 148.576 & 45.329 & 19.665 & 6.177 \\
\hline & p-level & .000 & .000 & .006 & .046 \\
\hline \multirow{2}{*}{ Unreliable } & $\chi^{2 *}$ & 119.274 & 26.101 & 22.216 & 0.935 \\
\hline & p-level & .000 & .002 & .002 & .626 \\
\hline \multirow{2}{*}{ Strict } & $\chi^{2 *}$ & 57.450 & 39.234 & 31.693 & 2.367 \\
\hline & p-level & .000 & .000 & .000 & .306 \\
\hline \multirow{2}{*}{ Hesitant } & $\chi^{2 *}$ & 219.650 & 44.854 & 30.160 & 1.820 \\
\hline & p-level & .000 & .000 & .000 & .403 \\
\hline \multirow{2}{*}{ Distracted } & $\chi^{2 *}$ & 252.134 & 30.146 & 27.586 & 1.172 \\
\hline & p-level & .000 & .000 & .000 & .557 \\
\hline
\end{tabular}

Table 3. Tests of marginal and partial association (significant interaction with the dependent variable included. "Choice" of the second and third grade for each characteristic for which they were disclosed at the level of $\mathrm{p}<0.05$ )

\begin{tabular}{|c|c|c|c|c|c|}
\hline \multirow{2}{*}{ Feature } & \multirow{2}{*}{ Effect } & \multicolumn{2}{|c|}{ Partial association } & \multicolumn{2}{|c|}{ Marginal association } \\
\hline & & $\chi^{2}(\mathrm{df})$ & p-level & $\chi^{2}(\mathrm{df})$ & p-level \\
\hline Submissive & Gender $\times$ Choice & $12.06(1)$ & .0005 & $11.67(1)$ & .0006 \\
\hline Indulgent & Gender $x$ Choice & $8.21(1)$ & .0042 & $7.96(1)$ & .0048 \\
\hline Moody & Gender $x$ Choice & $29.58(1)$ & .0000 & $29.18(1)$ & .0000 \\
\hline Quick tempered & Gender x Choice & $10.25(1)$ & .0014 & $10.08(1)$ & .0015 \\
\hline Strict & Gender $x$ Grade $x$ Choice & $12.18(2)$ & .0023 & $12.96(2)$ & .0015 \\
\hline Hesitant & Gender $x$ Grade $x$ Choice & $7.48(2)$ & .0238 & $9.21(2)$ & .0100 \\
\hline Distracted & Gender $x$ Grade $x$ Choice & $8.75(2)$ & .0126 & $8.66(2)$ & .0131 \\
\hline
\end{tabular}

Female students of grades I and II, more often than males in the same grades chose the feature strict as this, which should not be shown by the teacher (Fig. 2). The boys were more displeased at the teacher's indecision, and this was independent of the grade (Fig. 3). Distraction proved to be most unwanted for students from grade I and the least for grade III (Fig. 4).

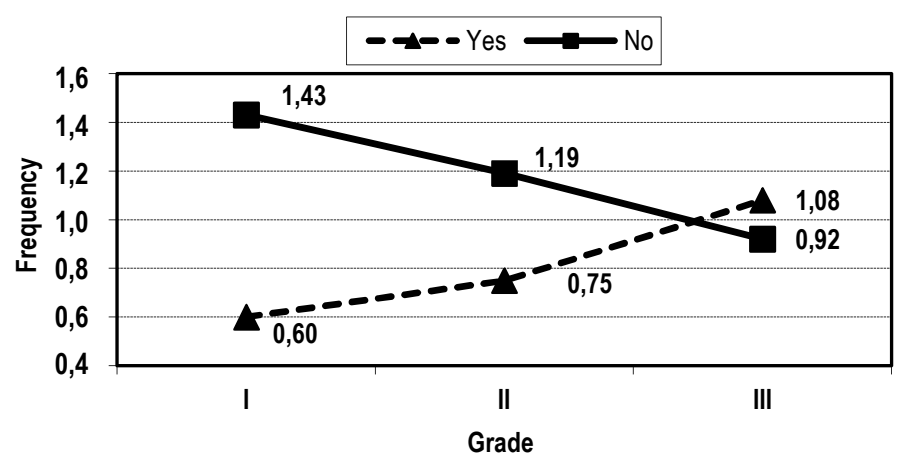

Figure 2. Ferquency quotient of choices of strict between male and female students 


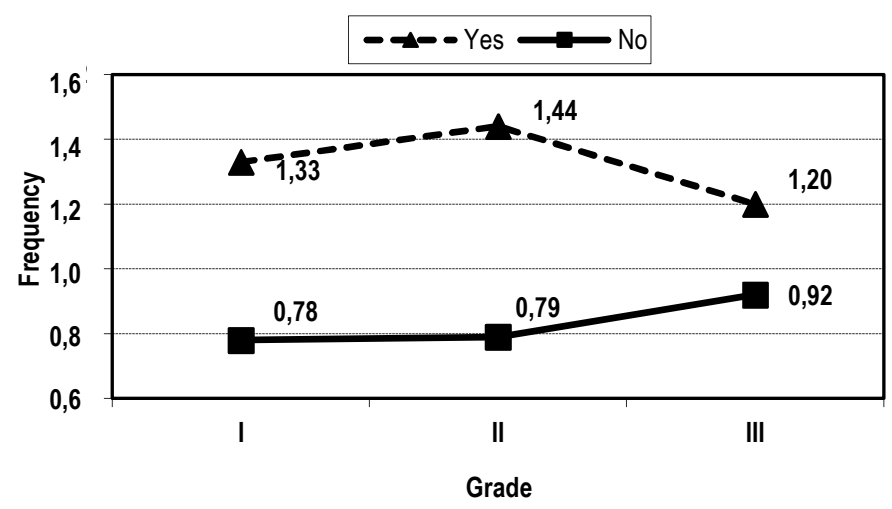

Figure 3. Ferquency quotient of choices of hestitant between male and female students

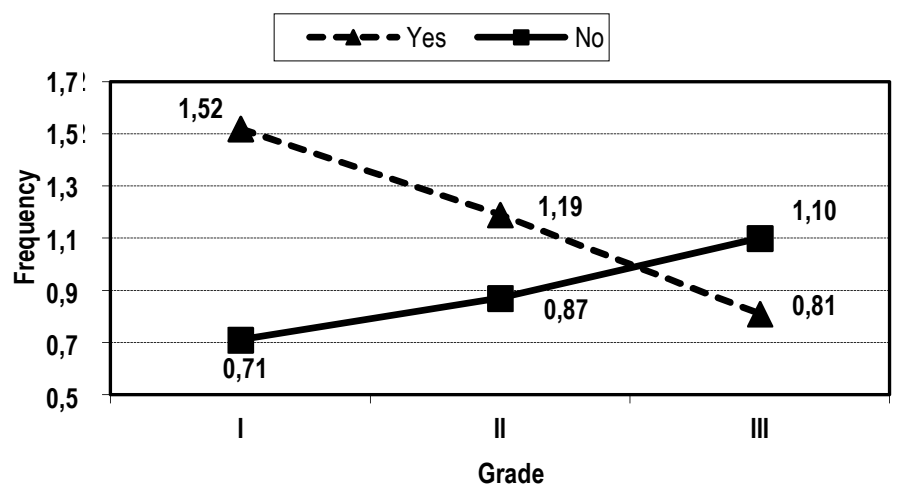

Figure 4. Ferquency quotient of choices of distracted between male and female students

\section{Discussion}

One of the important tasks faced by the teacher of physical education is to promote physical activity [8]. This is of particular importance in the modern world in which we observe a lower level of physical fitness and health $[9,10,11]$. Changing this situation requires the development of positive attitudes of youth towards physical education. According to both, women and men $[12,13]$, one of the factors, to a greater extent negatively than positively affecting this attitude is the teacher. Figley [14] came to just opposite conclusions. Regardless of the results obtained, the study shows clearly that the teacher (his personality, knowledge, actions) is an important determinant of creation of attitudes towards the physical education. The above considerations and analysis of research mainly focused on the positive qualities and skills that should characterize the teacher $[15,16,17]$, much less on the attempt to indicate the negative manifestations of misconduct [18], the causes and ways to eliminate them [19].

The analysis of undesirable features, performed in this article, is part of a wide range of contemporary reflections on the teacher's professional profile $[20,21,22]$. The study revealed that the most undesirable features of physical education teacher as perceived by the youth include violent expression of negative feelings (quick temper) and ruthlessness in enforcing the orders, as well as not taking into account any mitigating circumstances (strictness). Given the above, the most undesirable features are those whose manifestation by the teacher is associated with negative consequences for students. This is confirmed by studies of Zielinski [23], in which students as the most undesirable traits considered nervousness, lack of patience and undergoing mood. They also negatively assessed the excessive criticism, and maladjustment of requirements to their abilities.
Zalech: ELIMINATION OF NEGATIVE CHARACTER FEATURES...

Type of undesirable features indicated did not differ the respondents due to the school which they attended. The similarity of the choices made by students of both schools may be due to the homogeneity of the environment (the city) in which they operate, the same type of schools which they attend, and the similarity of problems faced during the physical education classes. Another variable, gender, proved to significantly differentiate respondents in the choice of such features as: compliant, indulgent, moody and quick tempered. One might assume that this is related to mental differentiation of both sexes, slightly different meaning of what they have for female and male students. The selection of features such as: strict, hesitant and distracted turned out to be conditioned by both gender and grade the respondents attended. And none of the analyzed independent variables determined the choice by respondents of the features: passive and unreliable.

Students most often characterized negative characteristics of teachers through the prism of their manifestations. These opinions have focused on identifying: communication difficulties, aversion to assist, ease to make one lose his temper, frequent shouting, malice, and aggressive behaviour [24]. It should be noted that the negative traits shown by the teachers are often enforced by the school environment. One reason for this is often a lack of procedures to deal with such problems, development of which would facilitate the work. The teacher would know how to act in certain situations, and students would have the awareness of what the consequences of their behaviour will be. There are more reasons for undesirable behaviour of teachers, among the main one can list: difficulties in dealing with parents, discouragement, stress, lack of motivation, personal problems [25, 26]. The teachers should be aware that manifesting of negative behaviour is often an important factor taken into account in the verification of teachers [27].

To conclude it should be emphasized that the elimination or reduction of manifestation by the teachers of negative features mentioned in the article should be considered as an important element of their building a positive image.

\section{Conclusions}

1. Knowing the expectations of students and determining the importance the negative features have on them is one of the important elements that should be taken into account in building the image of the teacher. Eliminating or reducing the manifestation of these features might contribute significantly to the positive perception of the teacher, and consequently, to improvement of relations with students and increase of the effectiveness of educational-teaching influence.

2. It would be advisable to ensure that when teachers take into account issues related to the image creation, with particular emphasis on the skills of elimination of negative behaviours, regardless of the difficulty and complexity of the situation which occur in school.

3. In teacher education more attention should be paid to the distinction between a consistent, firm conduct, and ruthlessness in enforcing orders, or imposing penalties. An important element of teacher education should also include development of skills of individual approach to different situations in interaction with various students, as well as paying more attention to the harm of excessive external expression of negative feelings and unpredictable behaviour on the educational process. Elimination of this type of conduct requires, among others, equipping the future staff with the skills of mastering emotions and knowledge how to deal with difficult situations. 


\section{Acknowledgements}

The research was accomplished within the framework of research project of Faculty of Physical Education and Sport in Biała Podlaska, The Josef Pilsudski University of Physical Education in Warsaw - BW. III/30 - financed by the Ministry of Science and Higher Education.

\section{Literature}

1. Echtner Ch.M. (2003). The meaning and measurement of destination image. J. Tourism Stud. 14(1), 37-48.

2. Manke, M.P. (1993). The rural teacher in the early 1900s: sentimental image and hard reality. J. Res. Rural Educ. 9(2), 57-65.

3. Sikorski, W. (2005). The image of the school in the opinion of students. Edukacja i Dialog 5, 54-57. [in Polish]

4. Naidoo, P., Ramseook-Munhurrun P. \& Durbarry R. (2010). Tourists' perspective of the brand image of Mauritius. Int. J. Management Market. Res. 3(3), 95-106.

5. Seitel, F.P. (2001). The Practice of Public Relations. New Jersey: Prentice Hall.

6. de Chernatony, L. (2001). From Brand Vision to Brand Evaluation: Strategically building and sustaining brands. Oxford: Butterworth-Heinemann.

7. Dalley-Trim, L. (2007) Students' observations and perceptions of teacher "performances" in the classroom. Aust. J. Teacher Educ. 32(1), 18-35.

8. Erdmann, R. (2009). Promoting health - a challenge to the school. Stud. Phys. Cult. Tourism 16(3), 269-280.

9. Bailey, D., Mirwald R., Faulkner R., Fairburn R. \& Owen W. (1982). Cardiorespiratory fitness in Canada: A current view. Can. Assoc. Health, Phys. Educ. \& Recreation J. 49(2), 2-8.

10. Sjolie, A.N. \& Monness E. (2007). Truncus endurance, hip and ankle mobility and aerobic fitness in 15-year-old Norwegian adolescents in 1968 and 1997. Scand. J. Med. Sci. Spor. 17, 488-496.

11. Przewęda, R. \& Dobosz J. (2003). Growth and physical fitness of Polish youths in two successive decades. J. Sport Med. Phys. Fit. 43(4), 465-74.

12. Luke, M.D. \& Sinclair G.D. (1991). Gender differences in adolescents attitudes toward school physical education. J. Teach. Phys. Educ. 11, 31-46.

13. Kucharska, E., Szymczak M. \& Pławińska L. (2003). Reasons for reluctance to participate in physical education classes in the opinion of students at different levels of education. In J. Jonkisz \& M. Lewandowski (Eds.), Education in the re- formed school (pp. 131-136). Wrocław: AWF Wrocław. [in Polish]

14. Figley, G.E. (1985). Determinants of attitudes toward physical education. J. Teach. Phys. Educ. 4, 229-240.

15. Demel, M. (1973). Critical Essays on Physical Culture. Warszawa: SiT.

16. Musgrove, F. \& Taylor P.H. (1972). Pupils' expectation of teachers. In A. Morison \& D. Mcintyre (Eds.), The social psychology of teaching (pp. 171-182). Portsmouth: NH, Heineman.

17. Arnona, S. \& Reichelb N. (2007). Who is the ideal teacher? Am I? Similarity and difference in perception of students of education regarding the qualities of a good teacher and of their own qualities as teachers. Teachers Teach. Theor. Pract. 13(5), 441-464.

18. Muszkieta, R. (2003). Teacher's manifestations of empathic behaviour in the process of monitoring and evaluating student achievement in physical education. In J. Jonkisz \& M. Lewandowski (Eds.), Education in the reformed school (pp. 131-136). Wrocław: AWF Wrocław. [in Polish]

19. Włodarski, Z. \& Matczak A. (1987). Introduction to psychology. Warszawa: Wydawnictwa Szkolne i Pedagogiczne. [in Polish]

20. Turhan, M. (2010). Social justice perceptions of teacher candidates. Educ. Res. Rev. 5(11), 668-673.

21. Cieśliński, R. (1991). Preparation for the Profession and Social Position of Physical Education Teachers. Warszawa: AWF Warszawa. [in Polish]

22. Poleszak, W. \& Bogucki J. (2000). Personality features of selected groups of teachers in view of psychological analysis. Edukacja, Studia, Badania, Innowacje 1, 30-43. [in Polish]

23. Zieliński, J. (2001). The modern image of the physical education teacher created by high school students. Przeglad Naukowy Instytutu Wychowania Fizycznego i Zdrowotnego Uniwersytetu Rzeszowskiego 4, 413-419. [in Polish]

24. Basiaga-Pasternak, J. (2002). Physical education teacher in the opinion of high school students. Studia Humanistyczne 2 , 31-40 [in Polish].

25. Brouwers, A. \& Tomic W. (2000). A longitudinal study of teacher burnout and perceived self-efficacy in classroom management. Teach. Teach. Educ. 16(2), 239-253.

26. Abel, M.H. \& Sewell J. (1999). Stress and burnout in rural and urban secondary school teachers. J. Educ. Res. 92(5), 287-293.

27. Nixon, A., Packard A. \& Douvanis G. (2010). Non-renewal of probationary teachers: negative retention. Education 131(1), 43-52.

Submitted: February 16, 2011

Accepted: April 12, 2011 